\title{
Законодательные и международно-правовые особенности охраны окружающей среды В Арктической зоне Российской Федерации
}

\author{
Ростунова O.C. ${ }^{*}$
}

В статье рассматриваются вопросы, связанные с применением советского, российского природоохранного законодательства к Арктической зоне РФ, вопросы о границах этой зоны, а также о роли Арктического Совета в области охраны окружающей среды Арктики.

Ключевые слова: Арктическая зона РФ; Арктический Совет; особо охраняемые природные территории.

В утвержденных 18 сентября 2008 года Президентом Российской Федерации «Основах государственной политики Российской Федерации в Арктике на период до 2020 и далее» ${ }^{1}$ используется, в качестве ключевого, термин «Арктическая зона Российской Федерации». Ранее, при толковании текста Постановления Президиума ЦИК СССР от 15 апреля 1926 г. «Об объявлении территорией СССР земель и островов, расположенных в Северном Ледовитом океане» ${ }^{2}$, отечественные специалисты по международному праву такой термин не использовали, а район действия данного Постановления называли «сектором полярных владений» государства. Именно в пределах этого сектора, как ранее считалось, действует природоохранное законодательство СССР и, впоследствии, России. Соответственно, возникают вопросы о применимости советского, российского природоохранного законодательства к Арктической зоне Российской Федерации и о точных границах этой зоны.

В «Основах... » дано новое следующее определение Арктики: «северная область Земли, включающая глубоководный Арктический бассейн, мелководные окраинные моря с островами и прилегающими частями материковой суши Европы, Азии и Северной Америки». Это

\footnotetext{
* Ростунова Ольга Сергеевна - аспирант кафедры международного права МГИМО (У) МИД России; научный сотрудник Центра правовых проблем СОПС при Президиуме PAH. olga_rostunova@mail.ru.

1 «Российская газета» - Центральный выпуск № 4877, 30.03.2009 г. (Далее - «Основы...»).

2 «Известия ЦИК СССР и ВЦИК», № 87, 16.04.1926.
} 
определение согласуется с распространенным в литературе по международному праву. Большая часть отечественных трудов по международному праву исходят из того, что термин «Арктика» означает часть земного сфероида, центром которой обозначен Северный географический полюс, а окраинной границей - Северный полярный круг (параллель 66 33' северной широты $)^{3}$.

Согласно «Основам...», «границы Арктической зоны Российской Федерации могут уточняться в соответствии с нормативными правовыми актами Российской Федерации, а также с нормами международных договоров и соглашений, участницей которых является Российская Федерация».

В соответствии с решением Государственной комиссии при Совете Министров СССР по делам Арктики от 22 апреля 1989 г. ${ }^{4}$, к Арктическим (северным) районам СССР отнесены территории Ненецкого, Ямало-Ненецкого, Таймырского (Долгано-Ненецкого), Чукотского автономных округов (полностью) и частично территории Республики Саха (Якутия), Красноярского края, Архангельской и Мурманской областей, земли и острова, указанные в Постановлении Президиума ЦИК СССР от 15 апреля 1926 г. «Об объявлении территорией СССР земель и островов, расположенных в Северном Ледовитом океане», внутренние воды и территориальное море, прилегающие к северному побережью Российской Федерации. Согласно Постановлению 1926 г. территорией Союза ССР объявлялись «все как открытые, так и могущие быть открытыми в дальнейшем земли и острова, не составляющие к моменту опубликования настоящего постановления признанной Правительством Союза ССР территории каких либо иностранных государств, расположенные в Северном Ледовитом океане, к северу от побережья Союза ССР до северного полюса» в пределах между меридианами, проходящими через восточную и западные оконечности территории страны. В таком контексте сочетание слов «земли и острова» может быть истолковано по-разному. Например, Е.А.Коровин говорил, что речь в постановлении идет о суверенитете государства в пределах обозначенного арктического сектора над: а) островами; б) ледовыми

${ }^{3}$ Международное право: учебник / предисловие С.В. Лаврова. Ред. коллегия А.Н. Вылегжанин, Ю.М. Колосов, Ю.Н. Малеев, Р.А. Колодкин. -М.: Высшее образование, Юрайт-Издат, 2009. С. 182.

${ }^{4}$ Архив СОПС при Президиуме РАН. 
пространствами; в) морскими пространствами, не спаянными льдом 5 . По мнению В.Л.Лахтина суверенитет каждого государства распространяется не только на наземные районы соответствующего арктического сектора, но и на воздушное пространство над ним. Что же касается современной международно-правовой литературы, то термин «земля», используемый в законодательстве России и Канады об арктических секторах, понимается не столь широко: термином «земли» уже не обозначаются «ледяные глыбы» и воздушное пространство. Вместе с тем, допускается (в частности, канадскими учеными) обозначение этим термином еще не открытых подледных земель, а также подводных (в том числе и тех подводных районов, которые составляют дно территориального моря и континентальный шельф) в пределах обозначенного полярного сектора страны. Термин «острова» в этих законодательных актах имеет обычное значение 6 .

Современное толкование обозначенных терминов имеет практическое значение и с точки зрения уточнения границ действия природоохранных мер по законодательству Канады, начиная с Закона Канады «О северо-западных территориях», принятом в 1907 году (в ред. 1925 г.), а также Королевского указа 1926 г., в котором использовано это же словосочетание "lands and islands". Современное право Канады допускает при этом понимание слова «земли» как означающего подледные и подводные земли в пределах канадского арктического сектора7

Как известно, в пределах Арктики, пять прибрежных к Северному Ледовитому океану государств Россия, Канада, США, Норвегия и Дания обладают своими внутренними морскими водами, территориальным морем, исключительной экономической зоной и континентальным шельфом в Северном Ледовитом океане. Из этих пяти наиболее развитое законодательство об охране окружающей среды в своем секторе имеет Канада. Она последовательно заявляет о своих природоохранных правах в Арктике с 1907 года, особенно продуманно и предметно прописанных в упомянутом законе «О северо-западных территориях». В нем же Канада определила свою арктическую территорию, включающую

${ }^{5}$ Цит. по: А. Vylegzhanin. Developing International Law Teachings for Preventing InterStates Disaccords in the Arctic Ocean. / Heidelberg Journal of International Law. 2009, № 69, p. 672 .

${ }^{6}$ Ibid. P. 673-676.

${ }^{7}$ Буник И.В., Николаев А.Н. Международно-правовое обоснование Канадой прав на ее арктический сектор // Московский журнал международного права. 2007, № 1. C. 4-33. 
все земли севернее параллели 60 северной широты, а также прибрежные районы заливов Гудзонова и Джеймса. В 1926 году Канадой был установлен «Заповедник арктических островов», северные гранищь которого совпадают с границами арктического сектора Канады ${ }^{8}$.

Вместе с тем, некоторые границы арктических секторов - и Канады, и России - были установлены еще раньше, посредством международных договоров.

Так, согласно Конвенциии об уступке Северо-американским Соединеннылм Штатам Российских Северо-Американских колоний (Конвенция об уступке Аляски) от 30 марта 1867 года, заключенной между Россией и Северо-Американскими Соединенными Штатами в Вашингтоне, обозначена граница, к востоку от которой все земли передавались Россией Соединенным Штатам Америки, а к западу оставались без изменения под суверенитетом России. Восточной границей являлась линия разграничения между российскими и британскими владениями в Северной Америке в соответствии с «Санкт-Петербургской Конвенцией с Англией относительно разграничения обоюдных пространств владений России и Англии в Северной Америке» от 16(28) февраля 1825 года. Западная граница уступленных территорий «проходит через точку в Беринговом проливе под 65 и 30' северной широты в ее пересечении меридианом, отделяющим на равном расстоянии острова Крузенштерна или Игналук от острова Ратманова или Нунарбук, и направляется по прямой линии безгранично к северу, доколе она совсем не теряется в Ледовитом океане».

Иначе говоря, можно предположить, что границы Арктической зоны Российской Федерации (АЗРФ) совпадают с границами, установленными обозначенными международными договорами России или национальным законодательством России секторальными (меридиональными) границами, если только более поздним международным договором России не будет установлена иная граница АЗРФ.

С учетом этого возникает другой важный вопрос: на международно-правовой или на национально-законодательной основе Российская Федерация осуществляет природоохранную юрисдикцию в Арктической зоне Российской Федерации?

Если говорить о международном уровне, то сегодня регулятивные природоохранные функции в этом регионе исходят, прежде всего, от Арктического Совета. Декларащия о создании Арктического Совета

${ }^{8}$ Там же. 
была подписана в 1996 году в Оттаве (Канада) полномочными представителями восьми арктических стран - Дании, Исландии, Норвегии, Финляндии, Швеции, США, Канады, России. Арктический совет был создан, прежде всего, для сотрудничества в области охраны окружающей среды Арктики и обеспечении устойчивого развития как средства улучшения экономического, социального и культурного благосостояния на Севере, включая сохранение арктической флоры и фауны, защиты арктической морской среды, борьбы с антропогенным загрязнением Арктики. Документы, принимаемые Арктическим Советом, юридически не обязательны, но их, тем не менее, государства стремятся исполнять. Принимаются во внимание интересы коренных народов, участвующих в обсуждении всех вопросов в качестве «постоянных участников», наряду с официальными представителями восьми арктических государств членов Арктического совета. Интересен здесь и механизм предметного учета интересов инвесторов, компаний, ведущих разведку и освоение природных ресурсов в рискованных условиях Арктики. В этом смысле показательна разработка Арктическим Советом Доклада 2007 года по нефти и газу в Арктике, обновленного Руководства по нефти и газу на континентальном шельфе, доклада «Оценка перспектив морского судоходства в Арктике» и др.

Структурно Арктический Совет опирается на шесть рабочих групп, которые отвечают за различные направления его деятельности:

- Рабочая группа по арктическому мониторингу и оценке (AMAР);

- Рабочая группа по сохранению арктической флоры и фауны $(\mathrm{CAFF})$;

- Рабочая группа по предотвращению чрезвычайных ситуаций, готовности к ЧС и реагированию на ЧС (EPPR);

- Рабочая группа по защите арктической морской среды (РАME);

- Рабочая группа по устойчивому развитию (SDWG).

В 1991 г. Министры восьми арктических государств подписали Декларацию о защчите арктической средь, где сформулирована Стратегия защиты окружающей среды Арктики. Целями данной Стратегии являются защита арктических экосистем; защита и восстановление качества окружающей среды; использование природных ресурсов и др.

Еще в 1993 году (т.е. до создания Арктического Совета) в Нууке, Гренландия, прошла вторая конференция на уровне министров арктических стран, ведающих вопросами защиты окружающей среды. В результате была принята Нуукская декларащия, в которой подтверждены 
обязательства защищать и сохранять окружающую среду Арктики, признана взаимосвязь между коренными народами, местным населением и состоянием Арктики, оценен их вклад в охрану окружающей среды Арктики. Было отмечено, что такая охрана требует принятия мер с учетом особенностей этого региона, а также предварительной оценки и систематического наблюдения за последствиями таких мер.

Третья Конференция на уровне министров по защите окружающей среды Арктики проводилась в марте 1996 г. Материалы данной конференции были систематизированы в Инувикской декларации о защите окружающей среды и устойчивом развитии в Арктике. Основными направлениями, обозначенными данным документом, являются разработка Арктических правил предотвращения загрязнения; готовности и реагирования на чрезвычайные ситуации; принятие мер для предотвращения и ответственности за загрязнения нефтью и газом и вовлечение в этот процесс коренного населения; подготовка анализа эффективности существующей системы уведомления о чрезвычайных ситуациях, а также анализ правоприменительной практики по существующим международным соглашениям ${ }^{9}$.

На четвертой Конференции на уровне министров по Стратегии защиты окружающей среды Арктики был проведен анализ хода выполнения Программы по предотвращению, готовности и реагированию на чрезвычайные ситуации, а также разработан план по анализу существующих систем уведомления о чрезвычайных ситуациях ${ }^{10}$.

В 2000 году на Аляске была принята Барроузская декларащия Арктического Совета. На данной встрече был одобрен и принят Рамочный документ по устойчивому развитию для продолжения сотрудничества по устойчивому развитию в Арктике, а также была выражена готовность арктических государств к защите арктической окружающей среды, одобрен План Арктического Совета по предотвращению загрязнения Арктики.

Третья встреча министров стран Арктического Совета проходила в г. Инари (Финляндия) в 2002 г. Министры, представляющие восемь Арктических государств, подписали Инарийскую Декларащию, в которой подтвердили стремление государств участников Арктического Совета и коренных народов Арктики работать совместно для защиты окружающей среды, уделять повышенное внимание проблемам

${ }^{9}$ Использованы материалы СОПС при Президиуме РАН.

10 Там же. 
изменения климата, использованию природных ресурсов и улучшению условий жизни в Арктике.

29 марта нынешнего года пять прибрежных арктических государств провели в Челси (Канада) вторую встречу на уровне министров иностранных дел и вновь подтвердили приверженность своей Илулиссатской декларации от 28 мая 2008 года.

Эти международные документы подтверждают сохраняющееся значение национально-законодательного регулирования арктическими государствами отношений, связанных с охраной окружающей среды в Арктике. Поэтому если оценить в общем плане правовой режим охраны окружающей среды в Арктической зоне Российской Федерации, то следует признать: он определен в основном актами российского законодательства.

Этот вывод подтверждает и текст «Основ...». Если представить интегральную таблицу по целевым сферам государственной политики Российской Федерации в Арктике, то в нее входят: национальные интересы Российской Федерации в Арктике; главные цели государственной политики Российской Федерации в Арктике; стратегические приоритеты государственной политики Российской Федерации в Арктике; основные задачи государственной политики Российской Федерации в Арктике; основные меры по реализации государственной политики Российской Федерации в Арктике.

Главные цели государственной политики Российской Федерации в Арктике - «обеспечение режима взаимовыгодного двустороннего и многостороннего сотрудничества Российской Федерации с приарктическими государствами на основе международных договоров и соглашений, участницей которых является Российская Федерация. К стратегическим приоритетам государственной политики Российской Федерации в Арктике относятся:

а) активизация участия российских государственных учреждений и общественных организаций в работе международных форумов, посвященных арктической проблематике, включая межпарламентское взаимодействие в рамках партнерства Россия - Европейский союз;

б) укрепление на двусторонней основе и в рамках региональных организаций, в том числе Арктического совета и Совета Баренцева / Евроарктического региона, добрососедских отношений России с приарктическими государствами, активизация экономического, научнотехнического, культурного взаимодействия, а также приграничного 
сотрудничества, в том числе в области эффективного освоения природных ресурсов и сохранения окружающей природной среды в Арктике;

в) разграничение морских пространств в Северном Ледовитом океане и обеспечение взаимовыгодного присутствия России на архипелаге Шпицберген; осуществление активного взаимодействия Российской Федерации с приарктическими государствами в целях разграничения морских пространств на основе норм международного права, взаимных договоренностей с учетом национальных интересов Российской Федерации, а также для решения вопросов международно-правового обоснования внешней границы Арктической зоны Российской Федерации.

Законодательство Императорской России, а также законодательство СССР об Арктике и обеспечение его выполнения сыграло значительную роль в признании на уровне международного обычного права действия национального природоохранного законодательства СССР/ России в пределах арктического сектора.

Ряд исключительных прав России в некоторых районах Арктики был изначально предусмотрен царскими указами 1616-1620 гг. и до советского законодательства, в котором были конкретизированы эти права. В 1821 г. Указом Правительствующего Сената Александр I принял в одностороннем порядке «Постановление о пределах плавания и порядка приморских сношений вдоль берегов Восточной Сибири, Северо-Западной Америки и островов Алеутских, Курильских и проч.» в соответствии с пунктом 1 которого «право торговли, китовой и рыбной ловли и всякой промышленности на островах, портах и заливах и вообще по всему северо-западному побережью Америки..., а также по островам Алеутским и по всем берегам Сибири предоставляется в пользование единственно российским поданным».

В 1921 году Советом Народных Комиссаров Советской России принят Декрет «Об охране рыбных и звериных угодий в Северном Ледовитом океане и Белом море» ${ }^{11}$. Данным Декретом в статье 2 провозглашались исключительные права РСФСР на эксплуатацию водных угодий для целей рыбной промышленности в промысловых районах Северного Ледовитого океана, примыкающих к арктическому побережью страны.

Указ Президиума ВС СССР от 26 ноября 1984 г. №1398-XI «Об усилении охраны природы в районах Крайнего Севера и морских районах, прилегающих к северному побережью СССР» (Закон СССР

${ }^{11}$ СУ РСФСР, 1921, № 49, ст. 259.С. 351-352. 
от 28 ноября 1984 г. №1422-XI «Об утверждении Указа Президиума Верховного Совета СССР «Об усилении охраны природы в районах Крайнего Севера и морских районах, прилегающих к северному побережью СССР») ${ }^{12}$ распространяется в соответствии со статьей 17 «на острова Северного Ледовитого океана и его морей, острова Берингова и Охотского морей, другие территории СССР, отнесенные Советом Министров СССР к районам Крайнего Севера, а также на прилегающие к северному побережью СССР морские районы (включая районы вокруг принадлежащих СССР островов), состояние которых влияет на экологическое благополучие северной части территории СССР» и предусматривает применимость природоохранного законодательства ко всему континентальному шельфу государства в Северном Ледовитом океане, в том числе за 200-мильным расстоянием от исходных линий ${ }^{13}$. Природоохранной целью данного Указа является в соответствии со статьей 2 создание «заповедников, заказников и других особо охраняемых территорий в районах Крайнего Севера и морских районах, прилегающих к северному побережью СССР» для «сохранения и восстановления природных комплексов, разработки научных основ охраны природы в этих районах, сохранения генетического фонда растений и животных, среды обитания, условий размножения и путей миграции животных, особенно редких и находящихся под угрозой исчезновения видов». В состав особо охраняемых территорий включаются материковые и островные участки, а также участки морского дна и водного пространства прилегающих к северному побережью СССР морских районов, включая районы, покрытые льдами. Согласно статье 11 данного Указа запрещается «сброс не очищенных до установленных норм сточных вод, а также отходов, материалов и предметов».

Применение российского природоохранного законодательства ко всему континентальному шельфу подтверждается статьей 2 части 3 Ф3 «Об охране окружающей среды» от 10 января 2002 года №7-Ф314. «Настоящий Федеральный закон действует на континентальном шельфе и в исключительной экономической зоне Российской Федерации в соответствии с нормами международного права и федеральными законами и направлен на обеспечение сохранения морской среды». Данный

12 «Ведомости Съезда народных депутатов СССР и Верховного Совета СССР», 28.11.1984 г., № 48, ст. 856.

${ }^{13}$ Использованы материалы СОПС при Президиуме РАН.

14 «Собрание законодательства РФ», № 2, 14.01.2002 г., ст. 133. 
закон определяет правовые основы государственной политики в области охраны окружающей среды, обеспечивающие сохранение природных ресурсов в целях экологической безопасности.

В Законе РСФСР № 2060-1 от 19 декабря 1991 года «Об охране окружающей природной среды» ${ }^{15}$ впервые были закреплены в разделе9 понятия «особо охраняемые природные территории и объекты», определены категории особо охраняемых природных территорий. Данный закон определял принципы охраны окружающей среды: сочетание экономических и экологических интересов, рациональное использование природных ресурсов. Закон устанавливал основные правовые институты охраны природы, особо охраняемые природные территории, требования к различным видам деятельности, виды экологического контроля и ответственность за них.

Современное российское природоохранное законодательство достаточно развито. Оно включает в себя законы, подзаконные акты, ведомственные акты и прочие. Законы определяют статус и деятельность особо охраняемых природных территорий и предусмотрена ответственность (уголовная, административная, материальная и дисциплинарная) за нарушения в сфере охраны окружающей среды и использования природных ресурсов.

Основу территориальной охраны природы в России составляет система особо охраняемых природных территорий. Согласно Федеральному закону от 15 февраля 1995 г. «Об особо охраняемых природных территориях» ${ }^{16}$ «особо охраняемые природные территории участки земли, водной поверхности и воздушного пространства над ними, где располагаются природные комплексы и объекты, которые имеют свое природоохранное, научное, культурное, эстетическое, рекреационное и оздоровительное значение, которые изъяты решениями органов государственной власти полностью или частично из хозяйственного использования, и для которых установлен режим специальной охраны». Настоящий Федеральный закон расширил перечень категорий особо охраняемых природных территорий в сравнении с ранее действующими нормами федерального законодательства. Теперь в соответствии со статьей 2 Закона выделяют следующие такие категории:

- государственные природные заповедники, в том числе биосферные;

15 «Ведомости Съезда народных депутатов Российской Федерации и Верховного Совета Российской Федерации», № 10, 1992 г., ст. 457

16 «Российская газета», № 57, 22.03.1995 г. 
- национальные парки; природные парки;

- государственные природные заказники;

- памятники природы;

- дендрологические парки и ботанические сады;

- лечебно-оздоровительные местности и курорты.

Полярные пустыни и арктические тундры, не смотря на их удаленность, страдают от негативных последствий хозяйственной деятельности человека. Поэтому большое внимание многими странами уделяется созданию специальных законодательных предписаний об охране природы в Арктике. Созданный в 1974 году Гренландский нащиональный парк в северо-восточной части острова Гренландия, является крупнейшим в мире. Его площадь составляет 70 млн.га. В США также созданы национальные парки. Среди них: «Ворота Арктики» (Gates of the Arctic National Park and Preserve). Является одним из самых больших национальных парков на Аляске, расположен на границе Арктики, полностью за полярным кругом; Катмай, расположенный в южной части штата Аляска и другие. Что касается Норвегии, то на архипелаге Шпицберген охраняемые природные территории занимают более 50\% суши. Самые крупные из них национальные парки Северо-Западный и Южный Шпицберген, Земля Принца Карла.

Самый большой заповедник Российской Федерации в Арктике образован Постановлением Правительства РФ от 11 мая 1993 г. №431 «О создании государственного природного заповедника "Большой Арктический" Министерства охраны окружающей среды и природных ресурсов Российской Федерации»17. Заповедник расположен на полуострове Таймыр и островах Северного Ледовитого океана на территории Таймырского автономного округа. Включает семь участков, в том числе остров Сибирякова, мелкие острова Карского моря, архипелаг Норденшельда, дельту реки Пясины, залив Миддендорфа, реку Нижняя Таймыра, полуостров Челюскин и др. Площадь заповедника составляет 4169,2 тыс. га. На всей территории Большого Арктического заповедника распространена многолетняя мерзлота. В заповеднике охраняются: белый медведь, островные популяции северного оленя, тюлени, белая чайка, орлан-белохвост, скопления водоплавающих и околоводных птиц.

Государственный природный заказник федерального подчинения «Земля Франца-Иосифа» создан 23 апреля 1994 года Распоряжением

17 «Собрание актов Президента и Правительства РФ», 17.05.1993, № 20, ст. 1846. 
Правительства РФ №571-р «О создании государственного природного заказника федерального значения «Земля Франца-Иосифа» ${ }^{18}$. Земля Франца-Иосифа (самая северная территория России между 80 и 82 северной широты) площадью 16134 кв. км покрыта льдом на 85\%. Растительностью занято 5-10\% свободной ото льда территории. Остальное пространство занимают каменистые россыпи, щебень и песок. Заказник создан в целях сохранения ландшафтов высокоарктических островов, в частности, мест размножения белого медведя, морских млекопитающих. Заказник находится в подчинении Главного управления природных ресурсов по Архангельской области.

Согласно Постановлению Совмина РСФСР от 23.03.1976 №189 «Об организации государственного заповедника «Остров Врангеля» Главохоты РСФСР в Магаданской области» 19 был учрежден природный заповедник «Остров Врангеля». Он расположен между Восточно-Сибирским и Чукотскими морями на островах Врангеля и Геральд с прилегающей к ним 12-мильной морской акваторией. Цель создания заповедника сохранение и изучение животного мира островной части Арктики. Он занимает площадь 2225,6 тысяч га, в том числе 1430000 га-морская часть. Несмотря на суровые климатические условия, в арктических тундрах растет более 300 видов растений. На острове Врангеля находятся самые крупные лежбища моржей.

Отношения, связанные с использованием природных ресурсов особо охраняемых природных территорий, регулируются также Водным кодексом Российской Федерации, Федеральным законом «О животном мире», Земельным кодексом Российской Федерации, а также Законом Российской Федерации «О недрах».

В Водном кодексе РФ от 03.06.2006 № 74-Ф320 в статье 66 установлено, что охрана и использование особо охраняемых водных или их части, имеющие особое природоохранное, научное, культурное, эстетическое, рекреационное и оздоровительное значение, осуществляются в соответствии с законодательством Российской Федерации об особо охраняемых территориях.

В принятом ФЗ от 24 апреля 1995 г. № 52-Ф3 «О животном мире» ${ }^{21}$ в статье 23 говорится, что «на территориях государственных природ-

18 «Собрание законодательства РФ», 02.05.1994, № 1, ст. 56.

19 Документ опубликован не был.

20 «Собрание законодательства РФ», 05.06.2006 г., № 23, ст. 2381.

21 «Собрание законодательства РФ», 24.04. 1995 г., № 17, ст. 1462. 
ных заповедников, национальных парков и на других особо охраняемых природных территориях охрана животного мира и среды его обитания осуществляется в соответствии с режимом особой охраны данных территорий, который устанавливается Федеральным законом «Об особо охраняемых природных территориях».

В Земельном кодексе Российской Федерации от 25.10.2001 №136Ф322 в статье95 также указывается, что относится к особо охраняемым природным территориям: «к землям особо охраняемых природных территорий относятся земли государственных природных заповедников, в том числе биосферных, государственных природных заказников, памятников природы, национальных парков, природных парков, дендрологических парков, ботанических садов, территорий традиционного природопользования коренных малочисленных народов Севера, Сибири и Дальнего Востока Российской Федерации, а также земли лечебно-оздоровительных местностей и курортов».

В соответствии с Законом РФ «О недрах» № 2395-1 от 21.02.199223 недра являются частью земной коры, расположенной ниже почвенного слоя, а при его отсутствии ниже земной поверхности и дна водоемов и водотоков, простирающейся до глубин, доступных для геологического изучения и освоения. Недра Арктики содержат дефицитные в России руды: важнейшие месторождения марганца - на Новой Земле, хрома в Ямало-Ненецком АО и Мурманской области, титана - на Кольском полуострове. Общая стоимость минерального сырья в недрах арктических районов России, по оценкам, превышает 30 трлн долларов, причем, две трети этой суммы приходится на долю энергоносителей. А общая стоимость разведанных запасов - 1,5-2 трлн долларов, что, по мнению экономистов РАН, свидетельствует о низкой степени освоения недр.

1 апреля 1996 года был издан Указ Президента России №440 «О Концепции перехода Российской Федерации к устойчивому развитию» 24 . В Концепции отмечена необходимость усиления работы по основным направлениям международной деятельности России в области охраны окружающей среды, в числе которых названо развитие и совершенствование системы особо охраняемых природных территорий.

Распоряжением Правительства Российской Федерации №1225р от 31 августа 2002 года одобрена Экологическая доктрина Российской

22 «Собрание законодательства РФ», 29.10.2001, № 44, ст. 4147.

23 «Собрание законодательства РФ», 06.03.1995, № 10, ст. 823.

24 «Российская газета», № 67, 09.04.1996. 
Федерации 25 . Она предусматривает создание и развитие особо охраняемых природных территорий разного уровня и режима в числе основных направлений государственной политики в области экологии.

Выводы:

1. Введение в российском правовом массиве нового понятия - Арктическая зона Российской Федерации - полностью согласуется с применимым международным правом, соответствует практике арктических государств по уточнению правового природоохранного режима Арктики, прежде всего посредством национального законодательства. Это понятие, как и понятие канадского законодательства «Канадская Арктика», не отменило законодательство двух арктических государств об их полярных секторах.

2. Южная граница Арктической зоны Российской Федерации определяется по территориальным границам не субъектов Российской Федерации, а городов, муниципальных образований, районов в пределах области, края, республики, территории которых выходят к побережью Северного Ледовитого океана.

3. Северная граница Арктической зоны Российской Федерации определяется границей континентального шельфа на основе международного договора РФ о делимитации с соответствующим соседним арктическим государством (с противолежащим или смежным побережьем).

4. Природоохранное российское национальное законодательство уже применяется к Арктической зоне Российской Федерации.

\section{Библиографический список}

Буник И.В., Николаев А.Н. Международно-правовое обоснование Канадой прав на ее арктический сектор // Московский журнал международного права. 2007, №1. - с. 4-33.

Международное право: учебник / предисловие С.В.Лаврова. Ред. коллегия А.Н.Вылегжанин, Ю.М.Колосов, Ю.Н.Малеев, Р.А.Колодкин.М.: Высшее образование, Юрайт-Издат, 2009. С. 182.

Vylegzhanin A. Developing International Law Teachings for Preventing Inter-States Disaccords in the Arctic Ocean. / Heidelberg Journal of International Law. 2009, №69, p. 672.

25 «Собрание законодательства РФ», 09.09.2002, № 36, ст. 3510. 


\section{Legislative and International Legal Features of the Environment Protection in the Arctic Zone of the Russian Federation (Summary)}

\section{Olga S. Rostunova*}

The article considers questions concerning the application of Soviet, Russian nature protection legislation to the Arctic zone of the Russian Federation, the limits of this zone, and the role of the Arctic Council in the Arctic environment protection sphere.

Keywords: The Arctic Zone of the RF; Arctic Council; specially protected natural territories.

\footnotetext{
* Olga S. Rostunova - post-graduate student of the Chair of International law, MGIMOUniversity MFA Russia; researcher at the Center of legal problems of the Council of Research of Productive Forces (SOPS), Russian Academy of Sciences.olga_rostunova@mail.ru.
} 